\title{
Polskie, czyli obce. O tłumaczeniach (nie)sławnego rozdziału Braci Karamazow Fiodora Dostojewskiego*
}

\author{
Kinga Rozwadowska
}

\author{
* Artykuł zawiera fragmenty książki Kingi \\ Rozwadowskiej pt. Przekład i władza. \\ Polskie tłumaczenia Braci Karamazow \\ Fiodora Dostojewskiego, Wydawnictwo \\ Uniwersytetu Jagiellońskiego, Kraków \\ 2018.
}

Powieść Fiodora Dostojewskiego pt. Bracia Karamazow funkcjonuje w polskiej literaturze od 1913 roku, czyli od momentu wydania pierwszego przekładu autorstwa Barbary Beaupré (choć wcześniej tłumaczono też i wydawano jako odrębne dzieło rozdział o Wielkim Inkwizytorze $\left.{ }^{1}\right)$. Można powiedzieć, że od tamtej pory dzieło to jest stale i wyraźnie obecne w naszej kulturze: było dotychczas wznawiane aż dwadzieścia trzy razy w sześciu przekładach². Największą popularnością cieszył się do niedawna przekład Aleksandra Wata z 1928 roku, jednak od 2004 roku jego największym „konkurentem” wydaje się tłumaczenie Adama Pomorskiego, które zyskało duży (również medialny) rozgłos i uznanie. Na początku XXI wieku wznawiano też kilkakrotnie przekłady Barbary Beaupré (mimo poważnych braków w tekście, a nawet sfałszowanego zakończenia!) i Wacława Wireńskiego z 1929 roku. Autorem najnowszego przekładu Braci Karamazow był Cezary Wodziński (2015 - publikacja ukazała się na kilka miesięcy przed śmiercią tłumacza).

\footnotetext{
${ }^{1}$ M. Zdziechowski przetłumaczył w swojej pracy pt. Mesjaniści i słowianofile fragmenty Wielkiego Inkwizytora (1888), a w 1907 roku J. Relidzyński opublikował przekład-adaptację dramatyczną tego rozdziału.

${ }^{2}$ Formalnie tłumaczeń jest pięć, jednak w niniejszym artykule będę zaliczać do serii przekładowej również publikację wydawnictwa Puls z 1993 roku, w której przekład Wata został „przejrzany i poprawiony” przez Z. Podgórca. Zmiany, jakie do tłumaczenia Wata wprowadził Podgórzec, stanowią na tyle głęboką ingerencję w tekst, że w mojej opinii pozwalają mówić o oddzielnym, szóstym tłumaczeniu.
} 
Jeden z najbardziej znaczących i oryginalnych aspektów polskiej recepcji powieści Dostojewskiego - w tym również recepcji w przekładach - koncentruje się wokół sceny, w której uczestniczą Polacy. Bohaterowie ci pojawiają się w karczmie w Mokrem, gdzie dochodzi do spotkania po latach Gruszeńki i jej pierwszego kochanka. Do karczmy przyjeżdża również Dymitr, który chce zapobiec powrotowi dziewczyny do jej ukochanego. Mitia, powodowany wyrzutami sumienia wypływającymi z przekonania o nieumyślnym zabiciu Grzegorza, a także lękiem przed gniewem Gruszeńki, stara się zachowywać wobec swojego polskiego rywala i jego towarzysza uprzejmie i z szacunkiem. Ci jednak nie odwzajemniają jego dobrej woli; zgromadzonych w karczmie Rosjan traktują podejrzliwie i z pogardą, demonstracyjnie podsycają konflikty o podłożu politycznym. W finale sceny okazuje się jednak, że w ślad za szumnymi wypowiedziami na temat polskiego honoru i czci dla dam idą czyny będące ich całkowitym zaprzeczeniem. Wychodzi na jaw, że Polacy cały czas oszukiwali, grając w karty, a ukochany Gruszeńki jest gotów odstąpić ją Dymitrowi i zniknąć w zamian za odpowiednią kwotę.

Recepcja tej sceny w Polsce musi wiązać się z próbą spojrzenia na siebie jako na Innego, z podjęciem trudu przyjrzenia się sobie oczyma drugiej osoby. Zdecydowanie większa część prac krytycznych i naukowych koncentruje się jednak wokół pytań dotyczących nie tyle sposobu pokazania Polaków, ile postaci samego Dostojewskiego. Negatywne i schematyczne przedstawienie Polaków motywowano doświadczeniem biograficznym pisarza ${ }^{3}$, jego poglądami politycznymi oraz względami religijnymi ${ }^{4}$. W odwrocie badaczy i interpretatorów od tekstu w stronę jego autora, w charakterze stawianych pytań skierowanych ad personam pobrzmiewa poczucie krzywdy i niesprawiedliwości, dla której wyjaśnienia należy szukać w rozmaicie nakreślonych kontekstach, poza powieścią mającą status arcydzieła ${ }^{5}$. Epizody, w których pojawiają się Polacy, wydają się skłaniać polskich badaczy do obarczania autora odpowiedzialnością za słowa i czyny swoich bohaterów, wbrew powszechnie aprobowanej Bachtinowskiej koncepcji polifonii. Czesław Miłosz całkowicie, lecz nie bez zdumienia, dyskredytował scenę z udziałem Polaków w Braciach Karamazow jako publicystyczną skazę na wielkim dorobku pisarskim Dostojewskiego: „wielki pisarz nie powinien się zniżać do takiego poziomu. To jest publicystyka!”’. Poeta podkreślał również, że epizod ten jest argumentem na rzecz ograniczeń polifonii: „Trudno o coś bardziej jednogłosowego niż scena z Polakami w Braciach Karamazow, płaska satyra nielicująca z powagą tego dzieła"7.

Jeśli nawet przyjmiemy, że w wymiarze ideowym omawiana scena rzeczywiście sprowadza się do homofonicznego, szyderczego głosu autora, to w wymiarze językowym jest jedną z naj-

\footnotetext{
${ }^{3}$ S. Mackiewicz, Dostojewski, Bielsko-Biała 1997; Z. Żakiewicz, Polacy u Dostojewskiego, [w:] tegoż, Ludzie i krajobrazy, Gdańsk 1970, s. 30-47.

${ }^{4}$ T. Rembowski, Polska i Zachód oczami Fiodora Dostojewskiego. Rosyjskie spojrzenie, „Sprawy Wschodnie” 2009, nr 1-2 (18--19), s. 87-100; J. Smaga, Wstęp, [w:] F. Dostojewski, Bracia Karamazow, przeł. A. Wat, oprac. J. Smaga, Wrocław 2013, s. III-CXL; J. Uglik, Polacy w powieściach i publicystyce Dostojewskiego, „Przegląd Powszechny" 2004, nr 11, s. 194-206.

${ }^{5}$ Jedyny znany mi wyjątek stanowi wnikliwy esej Jerzego Stempowskiego, który na podstawie porównawczej analizy konstrukcji bohaterów głównych i drugoplanowych powieści Dostojewskiego stawia tezę o ideach moralnych pisarza jako źródle negatywnej charakterystyki postaci Polaków. J. Stempowski, Polacy w powieściach Dostojewskiego, [w:] tegoż, Eseje, Kraków 1984, s. 229-250.

${ }^{6}$ C. Miłosz, Rosja. Widzenia transoceaniczne. Tom I. Dostojewski - nasz współczesny, wybór B. Toruńczyk i M. Wójciak, oprac. B. Toruńczyk, wstęp C. Cavanagh, Warszawa 2010, s. 175.

${ }^{7}$ Tamże, s. 101.
} 
barwniejszych i najbardziej wielogłosowych. Polacy są bowiem ośmieszeni przez autora nie tylko poprzez to, co robią, ale też przez to, jak mówią. W oryginale efekt komiczny wywołuje fonetyczny zapis polskich słów cyrylicą. Bohaterowie mówią najczęściej po polsku, z rzadka próbując dostosować swój język do rosyjskiej składni. Autor zaś występuje tu w roli tłumacza, który przekłada ich wypowiedzi na język rosyjski w nawiasie, nie zawsze zresztą dokładnie. Na przykład ukochany Gruszeńki, tłumacząc, dlaczego nie chce wypić toastu za Rosję, wypowiada następujące słowa:

- Але не можно не мець слабосьци о своего краю? - возгласил он. (Разве можно не любить своей стороны?) (FD, 513)

[ - Ale nie można nie mieć słabości do swojego kraju? [zdanie zapisane fonetycznie - K.R.] - wygłosił. (Czy da się nie kochać swojego kraju?)]

Dostojewski ujawnia swój głos w powieści nie jako autor, lecz jako tłumacz. Warto jednak zauważyć, że jako tłumacz ma on władzę równą niemal narratorowi auktorialnemu. Zdania w nawiasie objaśniają i interpretują słowa bohatera, wprowadzają do świata przedstawionego dodatkowe informacje, przekazują czytelnikowi wiedzę, która pomaga zrozumieć rozgrywającą się akcję. Obsadzenie siebie w roli tłumacza jest tu umiejscowieniem się w pozycji nadrzędnej i ujawnieniem tej pozycji. W ten sposób podważona zostaje harmonijna polifonia, a przedstawiona fikcja - ujęta w nawias, zawieszona. Autor-tłumacz przejmuje głos bohatera i kontrolę nad światem przedstawionym.

Nietrudno się domyślić, jak dużym wyzwaniem jest przetłumaczenie tak skonstruowanej sceny na język polski. Tłumacz musi bowiem jasno określić swoje miejsce w tekście, który już w oryginale posiada struktury przekładu i wpisaną nadrzędną instancję autora jako przekładającego. Osobne wyzwanie stanowi konieczność wyobcowania języka docelowego w tekście tłumaczonym, tj. przedstawienie języka polskiego jako obcego, a w konsekwencji - konieczność spojrzenia na bohaterów-rodaków jako na obcych. Paradoksalnie ich wypowiedzi powinny być dla polskich czytelników tak samo niezrozumiałe jak dla czytelników rosyjskich. Ponieważ jednak zrównanie perspektyw czytelnika tekstu źródłowego z docelowym jest niemożliwe, tłumacz staje się poniekąd "tłumaczem” drugiego stopnia, czyli objaśniającym swojemu czytelnikowi to, co autor-tłumacz objaśniał swojemu.

Część tłumaczy całkowicie porzuciła to wyzwanie. Najbardziej radykalne rozwiązanie zastosowała autorka pierwszego przekładu, Barbara Beaupré, która zupełnie wyeliminowała obcość (czyli w tym wypadku polskość) z tłumaczonego tekstu. W całym rozdziale nie ma najmniejszej wzmianki o tym, że dwaj bohaterowie pochodzą z Polski; wycięte zostały obszerne fragmenty rozmów dotyczących Polski i Polaków, a obydwie postaci mówią takim samym językiem jak pozostali bohaterowie. Ich obcość, ledwie zasygnalizowana w tekście, jest obcością niekonkretną, abstrakcyjną, obcością osób, które zbieg okoliczności niespodziewanie stawia Miti na drodze (ukochany Gruszeńki nazywany jest po prostu: nieznajomym, obcym panem). Jeżeli ci dwaj bohaterowie się czymś odróżniają od pozostałych, to nie językiem, lecz zachowaniem, na przykład teatralnie szarmanckim traktowaniem kobiety: 
- Jeżeli moja królowa nie ma nic przeciwko temu - zaczął wreszcie.

- Co tam królowa! Jaka królowa, dajcie już raz z tem pokój - przerwała niecierpliwie Grusza. Śmiesznie mi patrzeć na was i słuchać tego gadania (BB IV, 102-103).

Gruszeńka w powyższym przekładzie doskonale rozumie słowa swojego kochanka, ale nie rozumie jego zachowania. Co ciekawe, podobna strategia zastosowana została też w najnowszym przekładzie powieści. Chociaż Cezary Wodziński nie zataja już przed czytelnikami odmiennej narodowości „panów”, nie zaznacza jej również w sferze języka:

- Jeśli pozwoli moja królewna... - zaczął.

- Co za królewna, niby caryca, co? - przerwała nagle Gruszeńka. - Śmiech mnie bierze, jak słucham, co wy wszyscy gadacie (CW, 452).

W wybranej przez Wodzińskiego strategii zaskakujący jest nacisk na przekład międzykulturowy, z pominięciem aspektu międzyjęzykowego, tak jakby te dwie sfery dały się od siebie mechanicznie oddzielić.

Zupełnie inaczej wygląda ta wymiana zdań w przekładzie Aleksandra Wata, choć i on oddał obcość Polaków tylko częściowo. Bohaterowie w jego tłumaczeniu przekręcają pojedyncze wyrazy, na ogół jednak posługują się poprawnym językiem, takim jak pozostali bohaterowie:

- Jeżeli moja królewa pozwoli... - zaczął.

- Co za królewa, chyba królowa, co? - przerwała mu Gruszeńka. - Śmieszy mnie ta pańska mowa (AW II, 108).

Paweł Hertz jako pierwszy dostrzegł językową problematyczność przekładu Wata i wyjaśnił ją w następującym przypisie: „Polacy, występujący w rozdziale VII i następnych, mówią łamaną ruszczyzną, wtrącając słowa polskie. Trudno to oczywiście oddać w przekładzie polskim, lecz niewątpliwie należy zaznaczyć” (AW II, 512). Hertz zdaje się w ten sposób usprawiedliwiać przekładową porażkę w przypadku, gdy język przekładu jest zarówno przedmiotem, jak i podmiotem międzyjęzykowej gry. Problemu nie rozwiązano również w wersji Zbigniewa Podgórca, który w przekładzie Wata zmienił jedynie przekręcony wyraz królewa na królewiczowa i dołączył do niego identyczny przypis, w którym podobnie jak Paweł Hertz tłumaczy to, czego nie udało się oddać w przekładzie. Józef Smaga (a później też Grzegorz Przebinda) uznał propozycję Wata za niewystarczającą i postulował, aby pozostawić mowę Polaków Dostojewskiego w jej oryginalnym brzmieniu, tj. dokonać jedynie transliteracji na alfabet łaciński ${ }^{8}$. Adam Pomorski w swoim przekładzie nie skorzystał jednak z tej wskazówki:

- O wiele pozwoli moja królowa... - zaczął.

- Co znów za królowa, to ma być korolewa, tak? - przerwała mu nagle Gruszeńka - Śmiech mnie bierze was słuchać, jak wy wszyscy mówicie (AP, 504-505).

\footnotetext{
8 J. Smaga, Wstęp, s. CXXX; G. Przebinda, Piekło bez sufitu, [online] <http://www.rubl.uj.edu.pl/pracownicy/ fiszka.php?os=01_przebinda\&jed=KKSW\&opis=przeb_rzp1\&w=1>, [dostęp: 29.05.2013], nlb.
} 
Gruszeńka poprawia co prawda jedno słowo, ale całe zdanie, jakie wypowiada bohater, świadczy o jego językowym wyobcowaniu, o odmienności. Jest to zdanie nieprzystające do końca ani do języka źródłowego, ani docelowego. Przy tym jednak konkretne słowo, na które zwraca uwagę Gruszeńka, tłumaczone jest z języka polskiego na rosyjski, czyli przestaje być zrozumiałe dla polskiego czytelnika. Tłumacz nie objaśnia tego zabiegu, a zatem odwołuje się jedynie do czytelniczej świadomości, że nie obcuje bezpośrednio z dziełem Dostojewskiego, lecz z jego przekładem. Wysuwa fakt przekładu na pierwszy plan i burzy w ten sposób złudzenie ekwiwalencji.

O ile Adam Pomorski w powyższym fragmencie „wyjął” wypowiedź bohatera z porządku obydwu systemów językowych, o tyle Wacław Wireński zastosował proste odwrócenie. W jego przekładzie Polacy mówią po rosyjsku z niewielką domieszką polskiego:

- Jeżeli pozwolit moja królewa... - zaczął.

- Co za królewa - królowa chyba, czy co? - przerwała Grusza. - Aż mi się śmiać chce, jak wy obaj mówicie (WW, 268).

Strategia Wireńskiego paradoksalnie wiąże się z zawłaszczeniem i udomowieniem oryginału. Mowa Polaków jest niezrozumiała i dla pozostałych bohaterów, i dla czytelnika przekładu, a to sugeruje, że świat przedstawiony przynależy do tej samej kultury i języka, co odbiorca docelowy. W przyswojonym $\mathrm{w}$ ten sposób tekście język oryginału, czyli język rosyjski, może reprezentować obcość i tak też się dzieje. Odwrócenie, choć z pozoru czysto „mechaniczne”, wymierzone jest (świadomie lub nie) w autorytet pisarza, który z określonych powodów postanowił ośmieszyć właśnie Polaków jako naród. Całe ideowe podłoże tego zamysłu zostaje zniweczone przez fakt, że skompromitowani na końcu bohaterowie mówią w języku Dostojewskiego.

Tym, co zaburza przewrotnie symetryczny podział językowy w przekładzie Wireńskiego, jest kultura języka, a mianowicie wyśmiany zarówno w oryginale, jak i w większości przekładów zwyczaj (nad)używania tytułu „pan”. W oryginale hiperbolizacja tej cechy ówczesnej polszczyzny wywołuje efekt komiczny: nie tylko „panowie” Polacy tytułują tak pozostałych mężczyzn, „panuje” też Dymitr, z uprzejmości starający się dostosować do polskich obyczajów i mowy, nawet sam narrator nie mówi o ukochanym Gruszeńki inaczej niż „pan na kanapie”, „pan z fajką" (пан на диване, пан с трубкой - FD, 503-521). Dzięki zachowaniu tego zabiegu Wireńskiemu udaje się podważyć i skomplikować językową tożsamość postaci. Tłumacz dodatkowo wzmacnia ironiczny ton narratora, ujmując tytuł „pan” w cudzysłów. Wat i Podgórzec sygnalizują w ten sposób ironię jedynie na początku sceny. Z kolei Adam Pomorski dodatkowo wyostrza oryginalny humor i sięga też do starszych, jeszcze bardziej wymyślnych tytułów, takich jak wasindziej, mościpan, pan szlachta (AP, 504-505).

Język, jakim posługują się Polacy u Dostojewskiego, nie jest wartością stałą. Proporcje między językiem polskim a rosyjskim zmieniają się w zależności od sytuacji i od odbiorców. Na podstępne, przedmiotowe posługiwanie się językiem rosyjskim zwraca uwagę w pewnym momencie sam narrator. Najbardziej dosłownego przekładu tego komentarza dokonał Adam Pomorski: 
- Pan polskiej Pani na oczy nie widział i opowiada niestworzone rzeczy - uczynił pod adresem Maksimowa uwagę pan z fajką.

Pan z fajką mówił po rosyjsku całkiem przyzwoicie, w każdym razie znacznie lepiej niż dawał poznać. Słowa rosyjskie, jeżeli w ogóle ich użył, kaleczył na modłę polskich (AP, 508).

Uwaga narratora jest jasna w kontekście oryginału, w którym bohater mówi najczęściej po polsku, natomiast wypowiedź skierowana do Maksymowa jest mieszaniną rosyjskiego i polskiego (FD, 508). W przekładzie Pomorskiego należałoby albo potraktować ją jako uwagę ogólną, niezwiązaną z poprzedzającą ją wypowiedzią, albo przyjąć do wiadomości zaznaczoną już wcześniej umowność przekładu, w którym język polski „udaje” język rosyjski. Ponieważ bohater wcześniej wypowiadał zdania niezgrabne, dziwaczne, jego niespodziewane przemówienie poprawną polszczyzną jest „udawaniem” języka oryginału. W takim wypadku na pierwszy plan wysuwa się więc przekład jako konwencja, jako pewna strategia przedstawienia oryginalnego tekstu, która zarazem burzy czytelniczą iluzję obcowania bezpośrednio z tekstem oryginalnym.

Umowność przekładu jest inaczej zaznaczona w wersji Wata:

- Pan polskich pań na oczy nie widział i plecie niestworzone rzeczy - odezwał się na pół po polsku, na pół po rosyjsku pan z fajką.

Właściwie władał dobrze rosyjskim, w każdym razie o wiele lepiej niż udawał... Lecz przeplatał rosyjskie słowa polskimi i w dodatku przekręcał je umyślnie z polska (AW II, 111).

Chociaż i tutaj bohater wypowiada się poprawną polszczyzną, narrator zaprzecza „rzeczywistości” tekstu i proponuje czytelnikowi założenie, czy wręcz przyjęcie na wiarę tego, czego tłumacz nie był w stanie oddać. Celem narratorskiego wtrącenia jest zwrócenie uwagi czytelnikowi na fakt przekładu poprzez wskazanie jego ograniczeń (w tym wypadku: nieprzekładalności mieszaniny języka rosyjskiego i polskiego).

Na marginesie uwag do powyższego cytatu warto zaznaczyć wyjątkową trafność użytego przez Wata wyrażenia władać językiem. W kontekście omawianej sceny doskonale oddaje ono sposób, w jaki bohater posługuje się obcym językiem, a mianowicie wykorzystuje go i modyfikuje w zależności od celu, jaki chce osiągnąć. „Kaleczy” go, gdy chce podkreślić swoją obcość i zaznaczyć dystans w stosunku do Rosjan. Kiedy jednak do głosu dochodzą silniejsze emocje (tak jak w tym przypadku: oburzenie), bohater kształtuje swoją wypowiedź staranniej i poprawniej, aby miała większą siłę perswazji. Tym bardziej zaskakujące wydaje mi się, że wyrażenie władać językiem jest jedyną rzeczą, którą Zbigniew Podgórzec zmienił w przekładzie Wata (na: mówit; ZP II, 105). Ważnym elementem konstrukcji polskiego bohatera jest jego świadoma autokreacja budowana za pomocą narzędzi językowych w podobnym stopniu, w jakim sam autor tworzy tę postać poprzez jej język. Ten element utracił w swoim przekładzie Wacław Wireński, który każe bohaterowi konsekwentnie mówić w języku niezrozumiałym i dla innych postaci, i dla czytelnika:

- Pan polskoj pani nie widzieł i mówi to, co być nie mogło - zwrócił się do Maksymowa pan z fajką. Mówił po rosyjsku znacznie przyzwoiciej, niż udawał. Mimo to wszystkie słowa skandalicznie przekręcał (WW, 270). 
W tym wariancie narracja ma charakter auktorialny - ponieważ uwaga narratora nie ma właściwie przełożenia na prezentowaną w tej scenie rzeczywistość, należy przyjąć, że ujawnia on wiedzę niedostępną czytelnikom oraz pozostałym bohaterom.

Innym przykładem niestabilności i nieoczywistości języka polskiego bohatera jest moment, w którym Gruszeńka zgadza się, aby Dymitr dołączył do towarzystwa. W tłumaczeniu Adama Pomorskiego pan Mus(s)iałowicz ${ }^{9}$ odpowiada jej w miarę poprawną polszczyzną (czyli, jak ma założyć czytelnik - ruszczyzną), przez co podkreśla szacunek, jakim darzy dawną ukochaną: „Życzenie mojej władczyni jest prawem!” (AP, 505). W podobnie kwiecisty sposób bohater wypowiada się również w tekście Barbary Beaupré: „Wola mojej królowej jest dla mnie rozkazem!” (BB IV, 105-106). Tutaj jednak, ze względu na całkowitą jednolitość językową przekładu, wypowiedź ta nie niesie informacji o podstępności bohatera, a jedynie o jego szarmanckości. Ta zresztą w innych przekładach bywa również kwestionowana. Na przykład w wersji Aleksandra Wata: „Życzenie mojej królewej jest dla mnie prawem!” (AW II, 109) - bohater znów niespodziewanie wtrąca rusycyzm do swojej, poprawnej w innych miejscach, polszczyzny, a przy tym zdradza, że w ogóle nie przyjął do wiadomości wcześniejszej uwagi Gruszeńki na temat słowa królewa. Przekład ukształtowany w taki sposób przemyca jeszcze przed finałem sceny sugestię na temat rzeczywistego stosunku Mus(s)iałowicza do Gruszy. Zbigniew Podgórzec „poprawił” przekład Wata, każąc poprawić się bohaterowi: „Życzenie mojej królowej jest dla mnie rozkazem!" (ZP II, 102). Z takiego tłumaczenia można wnioskować o pełnej samokontroli bohatera, który panuje nad sobą i swoim/obcym językiem na tyle, by wywrzeć na odbiorcy zaplanowany efekt. Wacław Wireński i w tym wypadku stosuje konsekwentnie strategię „odwrócenia” języków: „Co przykażet moja caryca - to ustawa!” (WW, 268). Warto jednak zwrócić uwagę, że tylko Wireński i Wodziński pozostawili oryginalny tytuł nadany Gruszeńce - caryca. W wersji Wireńskiego wypowiedzi tej nie da się jednak zinterpretować w świetle poprzedniej, poprawionej przez bohaterkę, za to można w niej dostrzec ironię. W kontekście „upolitycznionego” stosunku Polaka do pozostałych bohaterów nazwanie Gruszeńki caryca stanowi nieco dwuznaczny wyraz podporządkowania i uległości.

Wymiany zdań między Gruszeńką i Mus(s)iałowiczem często krążą wokół zagadnienia przekładu. Dziewczyna przykłada dużą wagę do wypowiadanych przez swojego ukochanego słów, prosi o tłumaczenie, o wyjaśnienie, robi wszystko, aby zrozumieć człowieka, którego przed laty pokochała, nawet wtedy, gdy problem dotyczy najbardziej podstawowych problemów w komunikacji. Domagając się tłumaczenia, Gruszeńka usiłuje dotrzeć do prawdy o tym, co łączyło dawniej i co łączy ją teraz z Polakiem, bada, na ile jest jej wciąż znany, a na ile stał się obcy, próbuje odnaleźć wspólny język, jakim było łączące ich uczucie.

\footnotetext{
${ }^{9}$ Zapis nazwiska tego bohatera w niniejszym artykule scala dwa warianty obecne w polskich przekładach, przy czym Adam Pomorski jest jedynym tłumaczem, który zachował jego oryginalne brzmienie: Mussiałowicz. W przypisie Pomorski stwierdza, że poprzedni tłumacze niepotrzebnie poprawiali u Dostojewskiego zdwojoną spółgłoskę i że sugeruje ona przynależność bohaterów do szlachty kresowej. Przy tej okazji tłumacz zwraca uwagę na kontekst społeczny i literacki, w jakim należy interpretować omawianą scenę; stwierdza, że przedstawieni w niej Polacy to „postaci skądinąd typowe dla tzw. powieści antynihilistycznej, której rozkwit w Rosji zbiegł się z pogromem powstania styczniowego" (AP, 603). W ten sposób tłumacz próbuje chyba częściowo usprawiedliwić, a przynajmniej wytłumaczyć swoim czytelnikom negatywne przedstawienie Polaków określoną konwencją literacką.
} 
Gdy Dymitr proponuje Polakom grę w karty, ci z początku sprawiają wrażenie niechętnych pomysłowi:

- Późno, panie! - niechętnie odezwał się pan z kanapy.

- To prawda - przytaknął pan Wróblewski.

- „Późno”? Co to jest „późno”? - nie zrozumiała polskiego słowa Gruszeńka.

- „Późno” znaczy pozdno, proszę pani, pozdno, czas pozdnij (późna godzina) - przetłumaczył pan

z kanapy (AP, 514).

W powyższym przekładzie Adam Pomorski konsekwentnie eksponuje umowność formy przekładu (mówiąca po polsku Gruszeńka nie rozumie polskich słów). Jednak od tego momentu tłumacz zaczyna częściowo wprowadzać zabieg językowego „odwrócenia” w takim znaczeniu, w jakim stosował je Wacław Wireński. Odwrócenie nie jest jednak ani zupełne, ani konsekwentne. W odniesieniu do oryginału widać, że tłumacz właściwie powtarza gest Dostojewskiego, niekiedy tłumaczącego $w$ nawiasie słowa polskich bohaterów ${ }^{10}$. A zatem wtrącenia w nawiasach nie są inną formą przypisów tłumacza, lecz dokładnym odtworzeniem obecności autora, funkcjonującego w tekście na prawach tłumacza. Oczywiście nie sposób dostrzec tego zabiegu, nie znając oryginału, mimo to chwyt zastosowany przez Pomorskiego jest zgodny z logiką tekstu - bohater przechodzi z jednego języka na drugi, aby wyjaśnić niezrozumiałe dla osoby innej narodowości pojęcie. Tłumacz zaznaczył w ten sposób pojawiający się na marginesie dialogu problem: co to właściwie znaczy wy-tłumaczyć?

Wacław Wireński w swoim przekładzie zastosował identyczny mechanizm „przekładu w przekładzie":

- Pozdno, panie - jakby od niechcenia odezwał się pan na sofie.

- Pozdno, cóż to jest? - spytała Grusza.

- To znaczy późno, pani, późno, czas późny - wyjaśnił pan na sofie (WW, 274).

Ponieważ jednak tłumacz zamienił języki, jakimi posługują się bohaterowie, wyjaśnienia w nawiasach nie były już potrzebne. Przedstawiony w dialogu proces przekładu jest analogiczny do tego, jakiego dokonał tłumacz z języka oryginału i nie wymaga objaśniającego komentarza.

Przeciwnie do Wireńskiego i Pomorskiego postąpił Aleksander Wat, który zamiast zobrazować zagadnienie wy-tłumaczenia, postanowił je częściowo opisać, a częściowo przemilczeć:

- Późno, panie! - jakby niechętnie odezwał się „pan” z kanapy.

- To prawda - potwierdził pan Wróblewski.

Ponieważ powiedzieli to po polsku, więc Gruszeńka, nie zrozumiawszy ich, zapytała pana z fajką (AW II, 117).

\footnotetext{
${ }^{10}$ Zabieg ten pojawia się dwukrotnie również w przekładzie Cezarego Wodzińskiego, jednak w jego tekście ma on zupełnie inną wymowę - tutaj bowiem wszyscy bohaterowie mówią niezróżnicowaną, poprawną polszczyzną. Wydaje mi się więc, że $\mathrm{w}$ tej wersji ma on nie tyle sugerować umowność przekładu, co przede wszystkim budować efekt komiczny oparty na polisemii niektórych wyrazów wspólnych językowi polskiemu i rosyjskiemu, np. Pani, ja nie mam nic przeciw, nic nie skazałem (nic nie powiedziałem) [od ros. сказать (skazat') - powiedzieć - K.R.] (CW, 358). Być może tłumacz w ten sposób stara się dyskretnie zaznaczyć, że wspólnota językowa łącząca bohaterów jest pozorna.
} 
Z powyższego przekładu można wnioskować, że Wat postanowił poprzestać na zasygnalizowaniu umownego charakteru przekładu tej rozmowy i w konsekwencji zrezygnował z próby odtworzenia procesu przekładu w samym tekście. Zbigniew Podgórzec, wychodząc z tego samego założenia, przyjął podobną do Watowskiej strategię, postanowił jednak doprowadzić rozmowę w przekładzie do końca:

- Późno, panie! - jakby niechętnie odezwał się pan z kanapy.

- To prawda - potwierdził pan Wróblewski.

- Poźno? Co to takiego, późno? - zapytała Gruszeńka.

- Późno to późno, pani. Późna godzina - wyjaśnił pan z kanapy (ZP II, 110).

Tłumaczenie Podgórca jest przekładem całkowitym, to znaczy nie tylko przekładem z oryginału, ale też przekładem wewnątrz oryginału. W efekcie możemy dostrzec, jak niezbędny jest w tym dialogu dodatkowy komentarz czy to ze strony samego autora (i zachowany w przekładzie, jak u Pomorskiego), czy też tłumacza. Bez sproblematyzowania przekładu wewnątrz tekstu dialog między Gruszą i Polakiem wydaje się niemal absurdalny. W przekładzie Podgórca nie ma informacji ani o tym, że pytanie Gruszy odnosi się do zagadnienia językowego (a nie wynika to przecież z tekstu, który jest w całości skonstruowany w języku polskim), ani zaznaczenia faktu przekładu, jakiego dokonuje Polak. W tak dosłownym ujęciu, jakie prezentuje Podgórzec, odpowiedź pana z kanapy brzmi wręcz opryskliwie i w ten sposób zupełnie zafałszowuje obraz relacji między bohaterami.

Tymczasem problemy z komunikacją pomiędzy Mus(s)iałowiczem i Gruszeńką doskonale charakteryzują nie tylko samych bohaterów w danym momencie, ale również ich wspólną historię. Podczas rozmowy z ukochanym Gruszeńka zaczyna rozumieć, że Polak zapomniał o niej tak samo, jak zapomniał języka rosyjskiego. Uświadamia sobie, że stał się jej obcy, a niemożność odnalezienia wspólnego języka jest jedynie symptomem wygaśnięcia uczucia, które ich łączyło. Rozczarowanie i rozgoryczenie osiągają punkt kulminacyjny w momencie, gdy Mus(s)iałowicz po raz kolejny spolszcza jej imię:

- Pani Agrypino, dotknięty jestem do żywego! - zaczął podniesionym głosem, ale Gruszeńka nagle straciła resztę cierpliwości, jak gdyby trafił w najboleśniejsze miejsce.

- Po rosyjsku gadaj, po rosyjsku, nie waż się wtrącić ani jednego słowa polskiego! - wykrzyknęła.

- Dawniej mówiłeś po rosyjsku, czyżbyś zapomniał przez te pięć lat! - Była czerwona z gniewu.

- Pani Agrypino...

- Jestem Agrafiena, jestem Gruszeńka, gadaj po rosyjsku, albo słuchać nie chcę.

Pan nadął się z poczucia obrażonego honoru i łamaną ruszczyzną prędko i z namaszczeniem przemówił:

- Pani Agrafieno, ja przyjechał zapomnieć stare i przebaczyć, zapomnieć, co dzisiaj było... (AW II, 122; ZP II, 114-115).

Gruszeńka protestuje przeciwko zawłaszczeniu swojego imienia. Jej oburzenie skierowane jest przeciwko próbie jej podporządkowania, jest buntem przeciwko odzwierciedlonemu w języku władczemu gestowi nadawania nazw i narzucania znaczeń. Mus(s)iałowicz chce bowiem widzieć w Agrypinie „polską panią”, jedną z tych, którymi tak się chlubił przed rosyjskim to- 
warzystwem. Gruszeńka, przypominając mu swoje imię, przypomina mu o swojej tożsamości i o swoim pochodzeniu. Taką interpretację wyraźnie zaznaczył Zbigniew Podgórzec w obszernym przypisie do imienia Agrypina:

*Agrypina to imię pochodzenia greckiego, oznaczające osobę urodzoną nogami do przodu. Nosiła je święta, która poniosła śmierć za wiarę w Rzymie około $262 \mathrm{r}$. W Rosji popularne jest to imię w formie ludowej - Agrafiena (zdrobniale Grusza, Gruszeńka).

Tłumacz, jak się wydaje, celowo uwydatnił kontrast pomiędzy polskim a rosyjskim brzmieniem imienia bohaterki, za którym kryją się również różnice klasowe i kulturowe. Broniąc swojego imienia, Grusza broni też swojego prawa do gniewu i rewanżu - wymusza na rozmówcy przyjęcie swojego języka. Zmagania językowe bohaterów przeradzają się w zmagania o zapanowanie nad sytuacją, która ciąży coraz mocniej w stronę skandalu. W zacytowanej powyżej wersji Wata i Podgórca Polak niechętnie i nieznacznie dostosowuje się do żądania Gruszeńki. Z kolei w przekładzie Pomorskiego wysiłek Mus(s)iałowicza, który zmusza się do kompromisu, podkreślony jest dodatkowo zapisem rosyjskich słów kursywą:

- Pani Agrypino, jestem dotknięty do żywego! - zakrzyknął, Gruszeńka jednak straciła resztkę cierpliwości, jakby uraził ją w najboleśniejsze miejsce.

- Po rosyjsku, mów po rosyjsku, żebym ani jednego polskiego słowa nie słyszała! - huknęła na niego.

- Dawniej przecież mówiłeś po rosyjsku, co, przez pięć lat zapomniałeś? - poczerwieniała z gniewu.

- Pani Agrypino...

- Jestem Agrafiena, jestem Gruszeńka, mów po rosyjsku, albo słuchać nie chcę! - Pan zasapał

z poczucia honoru i kalecząc mowę rosyjską, przemówił szybko i napuszenie:

- Pani Agrafieno, ja przyjechał zabyć staroje i przebaczyć go, zabyć, co było przed siegodnia...

(AP, 519).

Co ciekawe, wymiana zdań na temat imienia bohaterki nie została pominięta w przekładzie Barbary Beaupré, która do tego momentu, usuwając wszelkie ślady sporu na tle narodowym, konsekwentnie zacierała różnice językowe między bohaterami.

- Panno Agrypino - zaczął - jestem do żywego dotknięty. - Ale Grusza przerwała mu niecierpliwie.

- Daj mi pan spokój z Agrypiną. - Nazywam się Agrafia, albo lepiej jeszcze Grusza. - Proszę nie przekręcać mego imienia.

- Proszę pamiętać, pani Agrafio, że przybyłem tu z zamiarem zapomnienia o przeszłości, gotów byłem wszystko przebaczyć, wszystko darować (BB IV, 114).

Nawet przy przemilczeniu wszelkich drażliwych kwestii o charakterze politycznym problem przemianowania najwyraźniej pozostał dla tłumaczki istotny, a reakcja bohaterki miała podkreślić jej gwałtowny, nieustępliwy charakter. Z kolei sam fakt przeinaczania imienia ukochanej wymownie świadczy o stosunku Mus(s)iałowicza do kochanki. W ten sposób przekład oddaje dramatyczny moment utraty złudzeń i wygaśnięcia miłości, bez odnoszenia się ani do kontekstów kulturowych źródłowego tekstu, ani do autorskich założeń publicystycznych. Zachowując z grubsza oryginalny obraz przemiany relacji między dawnymi kochankami, tłumaczka przemilcza wszystko to, co mogłoby urazić polskiego czytelnika. 
Wacław Wireński, przekładając tę wymianę zdań, wybrał rozwiązanie umiarkowane i nieco inaczej rozłożył akcenty: Gruszeńka nie odnosi się do języka i narodowości Mus(s)iałowicza, za to domaga się szacunku wobec swojego języka (i wobec niej samej):

- Pani Agrypina, jestem do żywego dotkniętym! - zaczął, lecz Grusza straciła nagle cierpliwość.

- Po rosyjsku gadaj, po rosyjsku i żebym jednego przekręconego słowa nie słyszała! Przecież przedtem mówiłeś, jak się należy; czyżbyś przez te pięć lat zapomniał? - zaczerwieniła się z gniewu.

- Pani Agrypina...

- Jestem Agrafiena, Grusza - gadaj jak się należy, albo słuchać nie chcę.

- Pani Agrafiena, ja przyjechał zapomnieć stare i przebaczyć, zapomnieć, co było do chwili dnia dzisiejszego... (WW, 276).

W przekładzie Wireńskiego podkreślony jest problem niepoprawności językowej, okaleczania i przekręcania słów, czyli zagadnienia szerszego niż przekład międzyjęzykowy. Tkwi w nim również większe prawdopodobieństwo umyślnego deformowania języka, które jest równie krzywdzące, jak zniekształcenie cudzego imienia.

Na zakończenie rozważań na temat uchwyconej w języku przekładów problematyczności relacji między bohaterami, kulturą źródłową i docelową oraz między autorem i tłumaczami chciałabym powrócić do symbolicznej, najczęściej komentowanej w polskiej recepcji sceny wznoszenia toastów. Gdy Mitia, po wzniesieniu toastu za Polskę, proponuje toast za Rosję, jego pomysł z entuzjazmem podchwytują kolejni (rosyjscy) bohaterowie, a Maksimow dopowiada:

- [...] za Rosję naszą starą, kochaną (AW II, 116; ZP II, 109).

- [...] i ja za Rosję, starą babunię... (WW, 273).

- [...] za Rassiejuszkę, starą babuleńkę (AP, 513).

Przekład Adama Pomorskiego wyróżnia się na tle pozostałych tłumaczeń dwoma znaczącymi zabiegami. Po pierwsze, w jego tekście Rosja zastąpiona została rosyjskojęzycznym deminutywem i tym samym wyobcowana, a wręcz „udziwniona”. Za słowem Rassiejuszka kryje się subtelna sugestia, że wszyscy bohaterowie w omawianej scenie są w jakiś sposób „obcy” polskim czytelnikom i że inność nie jest cechą charakteryzującą wyłącznie czarne charaktery, w tym wypadku Polaków. Tłumacz wydaje się w ten sposób kontestować czarno-białe podziały na swoje i obce, komplikować relacje międzynarodowe i międzyjęzykowe ustanowione przez autora oryginału. Pomorski, jak starałam się wykazać w niniejszym studium, często przypomina swoim czytelnikom o tym, że nie mają do czynienia z oryginałem, lecz ze specyficznym rodzajem tekstu, jakim jest przekład.

Drugą znaczącą decyzją tłumacza było opatrzenie powyższego fragmentu następującym przypisem: „Parodia zakończenia powieści Iwana Gonczarowa (1812-1891) Urwisko, w której silniejszy nad tęsknoty rodzinne okazuje się zew „innej, kolosalnej postaci, innej wielkiej «babuni» - Rosji”. Warto zwrócić uwagę, że nie jest to oryginalnie komentarz Pomorskiego, lecz przekład z jednego z rosyjskich wydań powieści ${ }^{11}$. Jednak zarówno w oryginale, jak i w

\footnotetext{
${ }^{11}$ Przypis odsyłający do dzieła Gonczarowa znalazłam w wydaniu powieści Братья Карамазовы z 1993 roku. Co ciekawe, z tego samego opracowania oryginału korzystał najprawdopodobniej również Z. Podgórzec, jednak wybierał i przekładał inne przypisy niż A. Pomorski. F. Dostojewski, Brat’ia Karamazovy, Elista 1993.
} 
przekładzie, przypis ten pełni podobną funkcję: nadaje przedstawianej scenie dodatkowy wymiar, dzięki któremu, przestaje być ona jedynie płaskq̨ satyrą na Polaków; wzbogaca znaczenie o dodatkowy kontekst literacki, który uświadamia czytelnikowi, że Dostojewski potrafił szydzić nie tylko z innej nacji i że teatralny patriotyzm dostrzegał i ośmieszał również wśród rodaków. W swoich „pozaprzekładowych” wypowiedziach Adam Pomorski często zaznacza, że jest przeciwnikiem przyklejania Dostojewskiemu etykietki „Polakożercy”. Przekład Braci Karamazow okazuje się miejscem, w którym tłumacz może wyrazić swoje stanowisko, wybierając i tłumacząc określony komentarz do oryginalnego tekstu. Pomorski jako tłumacz nie polemizuje z autorem oryginału, lecz z tradycją odczytywania jego dzieła w kulturze docelowej. W ten sposób podkreśla znaczenie przekładu jako elementu złożonej serii recepcyjnej ${ }^{12}$ obcego dzieła.

${ }^{12} \mathrm{~W}$ miejsce pojęcia „serii przekładowej” stosuję termin zaproponowany przez M. Skwarę jako szerszy i trafniej oddający różnorodność sposobów recepcji obcego dzieła w danej kulturze. M. Skwara, Polskie serie recepcyjne wierszy Walta Whitmana. Monografia wraz z antologia przekładów, Kraków 2014. 


\title{
SŁOWA KLUCZOWE:
}

\author{
seria przektadowa
}

HISTORIA PRZEKŁADÓW

\begin{abstract}
AbstrakT:
W artykule przedstawiono porównawczą interpretację tłumaczeń jednego z najbardziej kontrowersyjnych dla polskich odbiorców fragmentu powieści Dostojewskiego pt. Bracia Karamazow. Rozdział ten stanowi szczególnego rodzaju wyzwanie translatorskie zarówno pod względem ideowym (prześmiewcze przedstawienie Polaków jako jednowymiarowych Schwarzcharakterów powieści), jak i językowym (mieszanina języka rosyjskiego i polskiego, jaką posługują się bohaterowie). Wszystko to wymaga od tłumaczy spojrzenia na kulturę docelową i na siebie samych - jej przedstawicieli - jako na obcych. Celem niniejszego studium jest ukazanie, w jaki sposób autorzy polskich przekładów Braci Karamazow mierzą się z tym wyzwaniem lub uchylają się przed nim, oraz rozważenie czy i jak tłumaczom udaje się „obronić” wielkość Dostojewskiego jako światowej sławy pisarza w kulturze, do której odnosił się krytycznie, a nawet wrogo.
\end{abstract}


LITERATURA ROSYJSKA

\section{DOSTOJEWSKI}

\section{NOTA O AUTORzE:}

Kinga Rozwadowska (ur. 1987) - doktor nauk humanistycznych w zakresie literaturoznawstwa (obroniła na Wydziale Polonistyki Uniwersytetu Jagiellońskiego doktorat poświęcony polskim tłumaczeniom Braci Karamazow Dostojewskiego). Publikowała w czasopismach: „Przekładaniec”, „Między Oryginałem a Przekładem”, „Ruch Literacki”. Współautorka przekładu książki Theo Hermansa pt. Narada języków. Interesuje się teorią przekładu w szerokich ujęciach interdyscyplinarnych (socjologicznym, politycznym, ekonomicznym). 